\title{
TRADE PERSPECTIVES IN THE CONTEXT OF SAFETY, SECURITY, PRIVACY AND LOYALTY
}

\author{
Sanda Renko ${ }^{1} \&$ Blaženka Knežević ${ }^{2}$
}

UDK / UDC: 339.1:323.28(4-191.2)(4-11)(049.3)

JEL klasifikacija / JEL classification: F13

DOI: https://doi.org/10.22598/pi-be/2018.12.1. 185

Prikaz knjige / Book review

Primljeno / Received: 17. svibnja 2018. / May 17, 2018

Prihvaćeno za tisak / Accepted for publishing: 11. lipnja 2018. / June 11, 2018

Uz velik angažman članova Katedre za trgovinu Ekonomskog fakulteta iz Zagreba i zaduženje autora iz drugih inozemnih i domaćih institucija, iz tiska je izašla knjiga na engleskom jeziku pod naslovom Trade Perspectives in the Context of Safety, Security, Privacy and Loyalty. Poglavlja knjige uredile su izvanredna profesorica Blaženka Knežević i redovita profesorica Sanda Renko s Ekonomskog fakulteta u Zagrebu, a knjigu je izdao ugledni izdavač iz Ujedinjenog Kraljevstva Cambridge Scholars Publishing (ISBN 978-1-52750-841-5). Svi tekstovi prošli su međunarodnu recenziju. Ovo je još jedan primjer uspješne suradnje Katedre za trgovinu s inozemnim izdavačima.

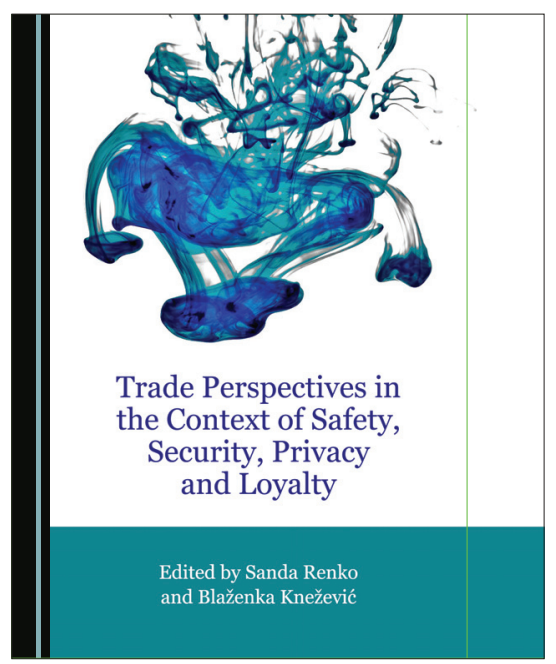

Rijetke su publikacije na temu trgovine i distribucije roba tako da se ovo djelo može opisati kao vrijedan doprinos u izučavanju trgovine. U jedanaest poglavlja knjige obrađene su teme koje danas neizostavno vežemo uz suvremenu trgovinu i operacije, a pokrivaju sigurnost trgovine i maloprodaje, utjecaj terorizma na tijekove roba, zaštitu od piratstva, privatnost kupaca u međunarodnim i domaćim transakcijama te razvoj koncepta lojalnosti. Može se zaključiti kako se glavni napori autora odnose na predlaganje mjera kako preventivno djelovati u organizacijama

1 Dr. sc. Sanda Renko, redoviti profesor, urednik, Ekonomski fakultet Sveučilišta u Zagrebu, Hrvatska, E-mail:srenko@efzg.hr

2 Dr. sc. Blaženka Knežević, izvanredni profesor, urednik, Ekonomski fakultet Sveučilišta u Zagrebu, Hrvatska, E-mail: bknezevic@efzg.hr 
i opskrbnim lancima da bi se spriječio nastanak sigurnosno-rizičnih situacija i stvorilo bolje povjerenje kupaca. Knjiga sadrži preko stotinu tabličnih i grafičkih prikaza, a na kraju knjige nalazi se i kazalo sa oko 250 relevantnih pojmova.

Ovo su goruće teme u znanstvenim i stručnim krugovima i sve je više relevantnih multidisciplinarnih istraživanja iz područja ekonomske sigurnosti tako da objavljeni tekstovi predstavljaju vrlo koristan, popularan i širok izvor znanja za znanstvenike i praktičare u međunarodnim okvirima. Okosnicu ove knjige čine odvojena istraživanja u kojima je sudjelovalo ukupno 28 prepoznatih autora iz Poljske, Hrvatske, Bosne i Hercegovine, Srbije i Makedonije koje zajednički povezuje tržište Središnje i Istočne Europe i specifičnosti koje tamo vladaju. Očito da je sigurnost i zaštita osobnosti danas visoko rangirani čimbenik kod donošenja odluke o kupnji jer izloženost i nepouzdanost mogu ugroziti integritet kupca i trgovca.

Pregledavajući sadržaj knjige vidljivo je kako su autorska poglavlja podjednakog opsega i strukture. U prvome poglavlju autori Baković, Dužević i Damić objašnjavaju negativan utjecaj međunarodnog terorizma na opskrbne lance roba i pokušavaju istražiti koliko su ti lanci otporni na takve rizične situacije. Razvijaju okvir preventivnih sigurnosnih mjera koje bi donekle mogle povećati spremnost opskrbe na nastanak terorističkih događaja. U drugome poglavlju autori Vuletić, Naletina i Polić pokušavaju identificirati težinu koliko terorizam utječe na funkcioniranje trgovine, turističkih dolazaka i BDP, a sve klasificiranjem činova terorizma. Time stvaraju novu podlogu za izučavanje izravnih i neizravnih učinaka terorizma na ove gospodarske grane. Knego i Mišević u poglavlju pod naslovom "Elementi za procjenu manjka u hrvatskoj trgovini na malo" proširuju kontekst sigurnosti na prodavaonicu. Autori ovog poglavlja se bave mjerenjem gubitaka i drugim učincima nastanka različitih tipova manjkova u prodavaonici na operativni rezultat. Nadalje, u četvrtom poglavlju Bombińska pomoću iscrpnih statističkih podataka objašnjava razinu sigurnosti koja vlada u međunarodnim prekomorskim opskrbnim lancima i naglašava nedovoljan angažman oko borbe s prijetnjama morskog piratstva. Ekonomske učinke krivotvorenih proizvoda na gospodarstvo i pojedine gospodarske grane obradili su Rački Marinković i Dunković. Ovi autori u petome poglavlju sa pravnog stajališta obrađuju TRIPS sporazum, okvir zaštite patenata i žiga, originalnost brenda i implikacije krivotvorenja proizvoda na sigurnost potrošača. U svome empirijskom istraživanju, pomoću ekonometrijskih modela, pokušavaju kvantificirati financijski učinak trgovine krivotvorenim proizvodima na propušteni promet trgovaca. U šestom poglavlju, autori Marić i Vukmirović, te u sedmom poglavlju autori Toschevska-Trpchevska, Kikerova i Makrevska Disoska istražuju implikacije potrošačke politike i međunarodnih sporazuma na sigurnost tijekova roba.

U sedmom poglavlju knjige provedeno je istraživanje o rizicima koji prate pretvaranje sporadičnih kupaca u lojalne gdje su Kovač, Novak i Tompić predstavili rezultate svog empirijskog istraživanja koje je imalo cilj usporediti sklonosti lojalnih i sporadičnih kupaca. Petković, Stojković i Knežević u osmom poglavlju istražuju m-trgovinu kao vrlo popularan trendi kanal u maloprodaji, međutim, izložen mnogim sigurnosnim rizicima kojemu je svojstven problemi privatnosti. Autori sa teorijskog stajališta obrađuju VUCA čimbenike neizvjesnosti i kompleksnosti kako bi pokazali u kojoj mjeri 
vlada sigurnost i privatnost u ovom kanalu maloprodaje na nacionalnom tržištu Srbije. Da postoje rizici i kod nisko-naponskih mikrolokacijskih uređaja koji se koriste u maloprodaji (npr. bluetooth, iBeacon), pokazali su autori Renko, Bošnjak i Peštek u desetom poglavlju knjige. Proveli su kvalitativnu studiju među maloprodajnim menadžerima u Hrvatskoj i kvantitativnu studiju na uzorku potrošača. Njihovi rezultati pokazuju na koji način ovi vidovi tehnologije mogu poboljšati iskustvo za kupce tijekom kupovine i kako unaprijediti maloprodajne operacije u cjelini. U posljednjem, poglavlju autorice Petljak, Štulec i Buljan provele su specijalno istraživanje lojalnosti u sektoru maloprodaje obuće i pomoću postignutih empirijskih rezultata pokazale što sve u ambijentu prodavaonice, i koji su to ostali čimbenici koji mogu pozitivno utjecati na lojalnost kupaca kod maloprodaje obuće.

Ovo znanstveno djelo u cjelini zasigurno će biti koristan izvor informacija za buduća istraživanja iz područja trgovine jer potiče na neke nove perspektive koje su do sada obilježavale i prate razvoj trgovine na tržištu Srednje i Istočnoj Europe. Međunarodni tim autora i recenzenata, te regionalna pokrivenost i aktualnost tema istraživanja osiguravaju ovoj knjizi izvrsnu prihvaćenost kod znanstvenika i stručnjaka.

Dr. sc. Dario Dunković, docent

Ekonomski fakultet Sveučilišta u Zagrebu

E-mail: ddunkovic@efzg.hr 